\title{
Characterization and Classification of the Soils of Bino-River Watershed in Almora District of Uttarakhand, India for Perspective Land Use Planning
}

\author{
S.K. Mahapatra ${ }^{1 *}$, Ritu Nagdev ${ }^{1}$, R.P. Yadav ${ }^{1}$ and S.K. Singh ${ }^{2}$ \\ ${ }^{1}$ ICAR-National Bureau of Soil Survey and Land Use Planning, \\ Regional Centre, IARI Campus, New Delhi, 110 012, India \\ ${ }^{2}$ ICAR-National Bureau of Soil Survey and Land Use Planning, Amravati Road, \\ Nagpur 440033, Maharashtra, India \\ *Corresponding author
}

\section{Keywords}

North western Himalayas, Binoriver watershed, Landform, Soil classification, Land evaluation

Article Info

Accepted:

04 February 2019 Available Online: 10 March 2019

\section{A B S T R A C T}

Soils of Bino-river watershed in Almora district of Uttarakhand, India in north western Himalayas were characterised and classified for land categorisation and perspective land use planning. On the basis of interpretation of remote sensing data and ground truth verification three broad landforms viz., ridge tops, side slopes and valleys were identified and further sub-divided into seven landform units based on slope gradients. Nine types of soils (Pedons 1 to 9) were identified in the watershed area. Soils of valleys (Pedons 1 to 3 ) occur on gentle to moderates lopes and are moderately deep to very deep, well to somewhat excessively drained, sandy loam, gravelly sandy loam and loamy sand to sand in texture and slightly acidic to neutral ( $\mathrm{pH} 6.11$ to 6.98) in reaction. They haveA-B-C horizons in pedon 1, being classified as coarse loamy Dystric Eutrudepts and A-C horizons in pedons 2 and 3, being classified as loamy skeletal Typic Udorthents and Typic Udipsamments. They are evaluated as class III and V lands. Soils of side slopes (Pedons 4 to 7) occur on moderate to steep slopes and are shallow to moderately shallow in depth, well to excessively drained, sandy loam, gravelly sandy loam and gravelly loamy sand in texture and moderately acidic to slightly acidic (pH 5.52 to 6.49) in reaction. They have A$\mathrm{C}$ horizons being classified as coarse loamy, sandy skeletal/loamy skeletal, Typic/Lithic Udorthents. They are assessed under class IV, V and VI land categories. Soils of ridge tops (Pedons 8 and 9) occur on moderately steep to steep slopes and are very shallow to shallow in depth, excessively drained, gravelly sandy loam in texture and moderately acidic (pH 5.64 to 5.95) in reaction. They have A-C and only Ahorizons and are classified as loamy skeletal Lithic Udorthents. They are evaluated as class VI and VII lands and not suitable for cultivation/plantations. The watershed area is prone to various kinds of degradation and hence proper soil and water conservation measures as well as good agronomic practices may be adopted to maintain soil health and increase productivity.

\section{Introduction}

Mountainous lands are at the risk of degradation and have serious impact on agricultural productivity and overall ecology. Thus, the development of the hilly region becomes a global concern for ecological balance and sustainable development of 
agriculture (FAO, 2015). The watershed management is an important tool for the sustainable development of mountainous region. The watershed management lays emphasis on the water conservation practices for assured irrigation. In the hilly region the watershed development is the appropriate technique for improving the agricultural productivity, alleviation of poverty, economic and overall development of the community (Nagdev et al., 2017a). For the development of any watershed area it is imperative to understand the inter-relationship among the landform, landuse and natural resources (Biswas, 1987; Mishra and Ghosh, 1995; Pai et al., 2007; Nagdev et al., 2018). Among the all natural resources, soil is the most prominent resource for developmental planning of any area (Mahapatra et al., 2005; Nagdev et al., 2017b). But its extensive use and continuous deterioration render serious threat to the ecology (Blum, 1997; Gorai et al., 2013). The management of soil should be efficient and judicious for sustainable agricultural production. Most of the researchers worked on the development of soils in some specific sites (Kumar and Sharma, 1987; Divakar et al., 1989; Rawatet al., 1994; Singh and Bhatnagar, 1997; Ghosh and Singh, 2002) but the information of soils in remote areas of Himalayan region is limited. Therefore, a concern for development of any watershed area through the management of soil resources is required for enhancing agricultural productivity. Mahapatra et al., (2018) reported that the Uttarakhand state is affected by moderate to severe soil erosion due to deforestation, human intervention, climatic instability and natural disasters and poses serious threat to agricultural productivity. Thus, the present study was undertaken to characterize and classify the soils of Bino-river watershed in Almora district of Uttarakhand in India for enhancing agricultural productivity and overall development of this hilly region.

\section{Materials and Methods}

\section{Study area}

The study area is Bino-river watershed which falls in warm humid Kumaon region of northwest Himalayas (Fig. 1). The area covers Chhani, Chachroti and Aphaukhala villages in Almora district of Uttarakhand. It represents agro-ecological sub region (AESR) No. 14.2 i.e. warm, moist dry sub-humid (Velayutham et al., 1999) and marked with rugged terrain having steep and high ridges. It lays between $29^{\circ} 47.5^{\prime}$ to $29^{\circ} 49.2^{\prime}$ latitudes and $79^{\circ} 12.1^{\prime}$ to $79^{\circ} 15^{\prime}$ longitudes covering 1463 ha area. The elevation ranges from 1012 to $1495 \mathrm{~m}$ above MSL. The mean minimum and maximum temperatures are $2{ }^{\circ} \mathrm{C}$ and $24^{\circ} \mathrm{C}$ and thus the area qualifies for thermic temperature regime (Walia et al., 2013; Gorai et al., 2013). The mean annual rainfall is about $1500 \mathrm{~mm}$. The soil moisture control section (SMCS) does not remain dry for 90 cumulative days in a year or does not remain dry for 45 consecutive days after summer solstice, thus qualifying the area for udic soil moisture regime.

\section{Delineation of landforms units}

IRS 1D LISS III geo-coded false colour composite (FCC) on bands 2, 3 and 4 were visually interpreted with Survey of India toposheet for delineation of the watershed and landform units (Sahu et al., 2016). The study area was traversed for ground truth verification of landform units and slopes in the field and base map was prepared for conducting soil survey work in the watershed area.

\section{Soil sampling and analysis}

Detailed soil survey was conducted using interpreted base map and soil pedons occurring on different landform units were studied in the field for their morphological 
characteristics (Sehgal et al., 1987; Bhattacharya et al., 2009). Soil samples were collected from the different horizons of representative pedons. Soil samples were analysed for their physico-chemical parameters viz., sand, silt, clay, soil reaction $(\mathrm{pH})$, electrical conductivity (EC), organic carbon (OC), cation exchange capacity (CEC), exchangeable cations $(\mathrm{Ca}, \mathrm{Mg}, \mathrm{Na}$ and $\mathrm{K})$ and base saturation (BS) using standard methods (Black 1965; Jackson 1966; Sharma et al., 1987).

\section{Soil classification and land categorisation}

Soils were classified as per Keys to Soil Taxonomy (Soil Survey Staff 2014) and the transect was prepared for establishment of soil-landscape relationship. The soils were evaluated for different land categories on the basis of site characteristics (climate, landform, slope and erosion) and limitation of soils based on properties viz., soil depth, texture, stoniness, rockiness and nutrient retention capacity (Sys, 1985; Sehgal, 1996). On the basis of land categories, ameliorative measures have been suggested for increasing productivity.

\section{Results and Discussion}

\section{Site characteristics of the soils}

On the basis of detailed soil survey conducted in the watershed area, nine soils (Pedons 1 to 9) have been identified. The site characteristics viz., landform, slope, parent material, erosion status and present land use of the soils are presented in Table 1. The broadland forms identified in the watershed are valleys, side slopes and ridge tops and further sub-divided into 7 landform units based on slope gradients. The transect showing all the soil pedons occurring on different landscapes (landform) has been depicted in figure 2. It is revealed that soils of pedons 1 and 2 occur on gently sloping valleys, developed on alluvium parent material and suffers from slight erosion problem. The present land use of both the soils is cultivation. Soils of pedon 3 occur on moderately slopping cultivated land in valleys, developed on mica schist/colluvium parent materials and are affected by moderate erosion. Pedon4 soils occur on moderately sloping cultivated side slopes, developed on quartzite parent material and suffer from moderate erosion problem. Pedon 5 soils occur on steep side slopes under forest, developed on mica schist parent material and suffer from severe erosion problem. Soils of pedon 6 occur on moderately steep side slopes under pasture land, developed on quartzite parent material and suffer from severe erosion. Soils of pedon 7 occur on moderately sloping hill sides under pastures, developed on mica schist and affected with moderate erosion problem. Pedon 8 soils occur on moderately steeply sloping ridge tops under forest, developed on quartzite parent material and suffer from severe soil erosion. Soils of pedon 9 occurs on steeply sloping ridge tops covered under shrubs and rocky land, developed on quartzite rock and suffer from very severe erosion problem.

\section{Morphological characteristics of soils}

The morphological characteristics of the soils of the watershed are described in Table 2. Soils of pedon 1 are very deep with Ap-A2Bw1-Bw2-Bw3-Bw4-C horizons; well drained; brown in colour; sandy loam in texture; medium, weak, sub-angular blocky in structure; slightly hard, friable, slightly sticky and slightly plastic in consistency having clear smooth and gradual smooth horizon boundaries. Soils of pedon 2 are very deep with Ap-A2-A3-AC-C1-C2-C3 horizons; well drained; brown to yellowish brown in colour; sandy loam in texture with strong gravels throughout the profile increasing downwards; 
massive in structure; slightly hard, friable, slightly sticky and non-plastic in consistency having clear smooth and gradual smooth horizon boundaries. Pedon 3 soils are moderately deep with Ap-A2-A3-C horizons; somewhat excessively drained; brown to yellowish brown in colour; loamy sand and sand in texture; single grain in structure; loose, very friable, non-sticky and non plastic in consistency having clear smooth, gradual smooth and abrupt smooth horizon boundaries underlain by unconsolidated bedrock at $85 \mathrm{~cm}$ depth. Soils of pedon 4 are moderately shallow in depth with Ap-A2-A3-C horizons; well drained; brown to yellowish brown in colour; sandy loam in texture with gravels throughout the profile; massive in structure; loose, friable, slightly sticky and non-plastic in consistency having clear smooth, gradual smooth and abrupt smooth horizon boundaries underlain by unconsolidated bedrock at $72 \mathrm{~cm}$ depth. Pedon 5 soils are moderately shallow having A1-A2-C1-C2 horizons; excessively drained; brown to yellowish brown in colour; loamy sand in texture with strong gravels throughout the profile increasing downwards; single grain in structure; loose, very friable, non-sticky and non-plastic in consistency having clear smooth, gradual smooth and abrupt smooth horizon boundaries underlain by unconsolidated bedrock at $73 \mathrm{~cm}$ depth. Pedon 6 soils are moderately shallow with A1-A2-C horizons; somewhat excessively drained; brown to dark yellowish brown in colour; sandy loam in texture with strong gravels throughout the profile; massive in structure; slightly hard, friable, slightly sticky and non-plastic in consistency having clear smooth and abrupt smooth horizon boundaries underlain by indurated bedrock at $69 \mathrm{~cm}$ depth. Soils of pedon 7 are shallow with A1A2-C horizons; excessively drained; brown to yellowish brown in colour; loamy sand in texture with strong gravels throughout the profile; single grain in structure; loose, very friable, non-sticky and non plastic in consistency having clear smooth and abrupt smooth horizon boundaries underlain by indurated bedrock at $48 \mathrm{~cm}$ depth. Pedon8 soils are shallow with $\mathrm{A}$ and $\mathrm{C}$ horizons; excessively drained; brown to yellowish brown in colour; sandy loam in texture with strong gravels in both horizons; massive in structure; slightly hard; friable, slightly sticky and non-plastic in consistency having clear smooth and abrupt smooth horizon boundaries underlain by indurated bedrock at $32 \mathrm{~cm}$ depth. Pedon 9 soils are very shallow with only one A horizon; excessively drained; brown in colour; sandy loam in texture with strong gravels (49\%); granular in structure; loose, very friable, non sticky and non-plastic in consistency having abrupt smooth horizon boundary underlain by indurated bedrock at only $11 \mathrm{~cm}$ depth.

\section{Physico-chemical properties of the soils}

The physico-chemical properties of the soils have been presented in Table 3. The soils of pedons 4, 5 and 7 are very coarse textured having loamy sand and sand texture with clay content varying from 2.75 to $8.50 \%$ only. The low clay content and coarser texture are due to the fact that these soils were developed from mica schist parent material. Whereas, other soils are coarse textured having sandy loam texture with clay content ranging from 9.50 to 15.50 percent as these soils were developed from quartzite/colluvium/alluvium parent materials. The soils are acidic in nature as revealed from their $\mathrm{pH}$ values. Pedon 5, 8 and 9 soils are moderately acidic ( $\mathrm{pH}$ ranges from 5.61 to 5.95) in reaction, whereas, pedons 3 and 6 soils are moderately to slightly acidic ( $\mathrm{pH}$ ranges from 5.52 to 6.34) and pedons 1 and 2 are slightly acidic to neutral ( $\mathrm{pH}$ ranges from 6.04 to 6.98 ) in reaction. The acidic nature of the soils is due to the leaching of bases from the soil profile as the landscape is sloppy. It is also revealed that $\mathrm{pH}$ is comperatively low in surface 
horizon than sub-surface horizons. This is due to the reason that organic carbon is high in surface layer than sub-surface layers. The electrical conductivity (EC) of all the soils is very low to low $\left(0.02\right.$ to $\left.0.51 \mathrm{dSm}^{-1}\right)$. The lower value of EC is due to the reason that landscape is sloppy and the soluble salts are removed from the horizons of soil profiles during the high intensive rainfall. Organic carbon (OC) content of all the soils is high to very high (0.77 to $2.07 \%)$ in surface horizons except pedon 3 which is medium $(0.67 \%)$. The enrichment of organic carbon is due to vegetative cover and its decomposition as the area falls under warm humid climatic conditions. It has also been observed that the organic carbon content is high in surface horizon and decreases downwards, as also observed by earlier authors (Mahapatra et al., 2000, 2005; Nagdev et al., 2017c). This is due to continuous decomposition and enrichment of OC in surface layers and its leaching downwards along the lower horizons. In subsurface horizons, the organic carbon content is mostly low ( 0.10 to $0.49 \%$ ) except pedons 4 and 6 . In pedon 4 , OC content is high $(0.82 \%)$ in second horizon and medium (0.52 to $0.61 \%$ ) in lower horizons whereas in pedon 6 it is high $(0.79$ to $1.02 \%)$ in both sub-surface horizons. It is also revealed from the Table 3 that the nutrient holding capacity of all the soils are very low to low as reflected from their CEC values (0.68 to $\left.5.31 \mathrm{cmol}(\mathrm{p}+) \mathrm{kg}^{-1}\right)$. It is low for pedons 1, 2, 4, 6, 8 and 9 (3.02 to $\left.5.31 \mathrm{cmol}(\mathrm{p}+) \mathrm{kg}^{-1}\right)$, whereas it is very low ( 0.68 to $\left.2.55 \mathrm{cmol}(\mathrm{p}+) \mathrm{kg}^{-1}\right)$ for pedons 3 and 5 and 7 , respectively. The lower CEC values of all the soils are due to the coarse to very coarse texture (sandy loam, loamy sand and sand) having less clay content (2.75 to $15.5 \%)$. The value of CEC is governed by finer soil particles i.e. clay and organic matter content of the soils (Nagdev et al., 2017a). The base saturation (BS) of pedons 4 to 9 is low $(50.69$ to $63.05 \%)$. This is due to the reason that these soils occur on higher elevations in hill slopes and bases are leached during high intensive rainfall prevailing in the area. The BS of pedons 1 to 3 is medium (65.17 to $73.57 \%)$. The comparatively high value of BS of these soils is due to the reason that these soils occur on lower elevations (valleys) and deposition of bases leached from higher elevations.

\section{Taxonomy of soils}

The soils of the study area have been classified as per USDA soil classification system and presented in Table 4. The temperature regime of the watershed area is thermic and moisture regime is udic, respectively. The mineralogy of all the soils has been found to be mixed type as revealed from the CEC: clay ratio which ranged between 24.72 and 36.00 (Smith, 1986; Nagdev et al., 2017c). Pedon 1 soils are very deep, well drained, sandy loam in texture with coarse gravels upto $11 \%$, sub angular blocky in structure (cambicepipedon) and have A, B and $\mathrm{C}$ horizons. Hence, they belong to Inceptisols with coarse loamy family textural class as the clay percent is less than 18 percent. The base saturation of these soils are more than $60 \%$ throughout the profile and no free carbonates in any of the horizons. Hence they belong to "Eutrudepts" great group and "Dystric" sub-group and classified as very deep, mixed, thermic, coarse loamy, Dystric Eutrudepts. Pedon 2 soils are very deep, well drained, sandy loam in texture with clay content less than $18 \%$ and strong coarse gravels upto $54 \%$ throughout the profile and have only $\mathrm{A}$ and $\mathrm{C}$ horizons. Hence these soils belong to Entisols with loamy skeletal family textural class and classified as very deep, mixed, thermic, loamy skeletal, Typic Udorthents. Soils of pedon 3 are moderately deep (upto85 cm depth), somewhat excessively drained, loamy sand and sand in texture with coarse gravels upto 19\% and have only $\mathrm{A}$ and $\mathrm{C}$ horizons. Hence, these 
soils belong to Entisols with sandy textural class and classified as moderately shallow, mixed, thermic, Typic Udipsamments. Pedon4 soils are moderately shallow (upto 72 $\mathrm{cm}$ depth), well drained, sandy loam in texture with clay content less than $18 \%$ and coarse gravels upto $24 \%$ and have only A and $\mathrm{C}$ horizons. Hence they belong to Entisols with coarse loamy family textural class and classified as moderately deep, mixed, thermic, coarse loamy, Typic Udorthents. Pedon 5 soils are moderately shallow (upto $73 \mathrm{~cm}$ depth), excessively drained, loamy sand in texture with strong gravels upto $47 \%$ throughout the profile and have only $\mathrm{A}$ and $\mathrm{C}$ horizons. Hence these soils belong to Entisols with sandy skeletal textural class and classified as moderately shallow, mixed, thermic, sandy skeletal Typic Udorthents. Pedon 6 soils are moderately shallow (upto 69 $\mathrm{cm}$ depth), somewhat excessively drained, sandy loam in texture with strong gravels upto $44 \%$ throughout the profile and have only $\mathrm{A}$ and $\mathrm{C}$ horizons. Hence they belong to Entisols having loamy skeletal textural class and classified as moderately shallow, mixed, thermic, loamy skeletal, Typic Udorthents. Soils of pedon 7 are shallow (upto $48 \mathrm{~cm}$ depth), somewhat excessively drained, sandy loam and loamy sand in texture with strong gravels upto $47 \%$ throughout the profile and have $\mathrm{A}$ and $\mathrm{C}$ horizons underlain by indurated bedrock at $48 \mathrm{~cm}$ depth. Hence these soils belong to Entisols having sandy skeletal textural class and classified as shallow, mixed, thermic, sandy skeletal, Lithic Udorthents. Pedon 8 soils are shallow $(32 \mathrm{~cm}$ depth), excessively drained, sandy loam in texture with strong gravels upto 52\% throughout the profile and have $\mathrm{A}$ and $\mathrm{C}$ horiozons underlain by indurated bedrock at $32 \mathrm{~cm}$ depth. Hence, they belong to Entisols having loamy skeletal family textural class and classified as shallow, mixed, thermic, loamy skeletal, Lithic Udorthents. Soils of pedon 9 are very shallow (upto $11 \mathrm{~cm}$ only), excessively drained, sandy loam in texture, with coarse gravels upto $49 \%$ and have only A horizon underlain by indurated bedrock at $11 \mathrm{~cm}$ depth. Hence, these soils belong to Entisols with loamy skeletal textural class and classified as shallow, mixed, thermic, loamy skeletal, Lithic Udorthents.

\section{Land categorisation for land use planning}

The watershed area has been evaluated into different land category classes based on their limitations, potentials as well as site characteristics for suggesting measures for optimum productivity. Table 5 represents the different land categories of the nine soil pedons of the watershed and their suggestive measures. Pedon 1 soils occur on gently sloping valleys having limitations of coarse texture (sandy loam), low nutrient holding capacity (CEC varies from 3.50 to $5.31 \mathrm{cmol}$ $\left.(\mathrm{p}+) \mathrm{kg}^{-1}\right)$ and slight erosion. They were evaluated as class III lands and can be cultivated for climatically adapted crops applying required doses of organic and inorganic fertilisers and land leveling. Pedon 2 soils also occur on gently sloping valleys and have limitations of coarse texture (sandy loam) with strong gravelliness, low nutrient holding capacity (CEC ranges from 3.33 to $\left.4.35 \mathrm{cmol}(\mathrm{p}+) \mathrm{kg}^{-1}\right)$ and slight erosion. They are evaluated as class III lands and can be cultivated for crops adapted to climate and soil limitations applying recommended doses of organic and inorganic fertilisers. Pedon 3 soils occur on moderately sloping valleys having limitations of soil depth (upto85 cm), very coarse texture (sand and loamy sand), very low nutrient holding capacity (CEC ranges from 0.68 to $\left.1.95 \mathrm{cmol}(\mathrm{p}+) \mathrm{kg}^{-1}\right)$ and moderate erosion. They are categorised under class V lands and as such not suitable for cultivation of crops but suitable for pastures. However these lands can be utilised for cultivation adopting proper soil and water conservation measures like land leveling, 
integrated nutrient management (INM) practices including recommended doses of organic and inorganic fertilisers and frequent timely irrigations. Soils of pedon4 occur on moderately sloping side slopes of hills and have limitations of limited soil depth (upto $72 \mathrm{~cm}$ ), coarse texture (sandy loam), moderate stoniness, low nutrient holding capacity (CEC ranging from 3.75 to 4.66 cmol $\left.(\mathrm{p}+) \mathrm{kg}^{-1}\right)$ and moderate erosion. They were categorised under class IV lands and can be cultivated for crops adapted to limitation of soils and application of proper soil and water conservation measures and good agronomic practices. Soils of pedon5 occur on steeply sloping hills under forest and have severe limitations of soil depth $(73 \mathrm{~cm})$, very coarse soil texture (loamy sand), strong gravelliness, very low nutrient holding capacity (CEC ranges from 2.16 to $\left.2.46 \mathrm{cmol}(\mathrm{p}+) \mathrm{kg}^{-1}\right)$ and severe erosion. They are assessed as class VI lands and not suitable for cultivation but can be utilised for pastures/forestry adopting proper soil and water conservation practices to prevent erosion. Pedon6 soils occur on moderately steeply sloping pasture lands and have limitations of soil depth (upto $69 \mathrm{~cm}$ ), coarse texture (sandy loam) with strong gravelliness, low nutrient holding capacity (CEC varies from 3.02 to $3.37 \mathrm{cmol}(\mathrm{p}+) \mathrm{kg}^{-1}$ ) and severe erosion. They are assessed as class $\mathrm{V}$ lands and as such not suitable for cultivation but can be brought under cultivation adopting conservation measures like construction of engineering structures to prevent erosion, application of good agronomic practices and selection of plants adapted to limitation of soils. Soils of pedon 7 occur on gently sloping hillsides under pastures having limitations of shallow soil depth (upto $48 \mathrm{~cm}$ ), moderate erosion, very coarse soil texture (loamy sand) with strong gravelliness and very low nutrient holding capacity (CEC ranges from 1.30 to $2.55 \mathrm{cmol}$ $\left.(\mathrm{p}+) \mathrm{kg}^{-1}\right)$. They are evaluated under class VI land category and not suitable for cultivation but can be utilised for pastures by adopting soil and water conservation measures. Pedon 8 soils occur on moderately steeply sloping hills under forest and have severe limitations of shallow soil depth (upto $32 \mathrm{~cm}$ ), coarse texture (sandy loam) with strong gravelliness, low nutrient holding capacity (CEC ranges from 4.12 to $\left.5.10 \mathrm{cmol}(\mathrm{p}+) \mathrm{kg}^{-1}\right)$ and severe erosion. They are assessed as class VI lands and not suitable for cultivation but can be utilised for pastures/plantations with proper engineering structures to prevent erosion. Pedon 9 soils occur on steeply sloping hills under shrubs/rocky landscape and have very severe limitations of very shallow soil depth (upto $11 \mathrm{~cm}$ only), rockiness, coarse texture (sandy loam) with strong gravelliness, low nutrient holding capacity (CEC $3.52 \mathrm{cmol}$ $\left.(\mathrm{p}+) \mathrm{kg}^{-1}\right)$ and very severe erosion. They are evaluated under class VII land category and are not suitable for cultivation or plantations but can be utilised for grazing/pastures after construction of proper engineering structures to prevent erosion.

Thus, it is revealed that the watershed area is prone to various kinds of degradation problems affecting productivity. The degradation is due to sloppy landscape, indiscriminate use and over exploitation of land resources due to pressure of increasing population, deforestation and eratic rainfall prevailing in the area.

Hence, suitable soil and water conservation measures should be adopted like construction of engineering structures viz., contour trenching, bench terracing, staggered trenching, contour furrows, etc. to prevent erosion. Fallow lands may be covered with grasses/ shrubs as well as plantations to protect from degradations and improve soil quality (Dhayani et al., 2005; Prasad and Dhayani, 2010; Nagdev et al., 2017d). Besides, good agronomic practices may be adopted viz., strip cropping, inter cropping 
with legumes, mulching, INM practices with proper doses of organic and inorganic fertilizer, etc for maintenance of soil health and increasing productivity.

Table.1 Site characteristics of the soil pedons

\begin{tabular}{|c|c|c|c|c|c|}
\hline Soils & Landform & Slope (\%) & Parent material & Erosion status & Present land use \\
\hline Pedon 1 & Valley & Gentle (3-5) & Alluvium & Slight & Cultivated \\
\hline Pedon 2 & Valley & Gentle (3-5) & Alluvium & Slight & Cultivated \\
\hline Pedon 3 & Valley & Moderate (5-10) & $\begin{array}{l}\text { Mica schist } \\
\text { /Colluvium }\end{array}$ & Moderate & Cultivated \\
\hline Pedon 4 & Side Slope & Moderate (5-10) & Quartzite & Moderate & Cultivated \\
\hline Pedon 5 & Side Slope & Steep (15-25) & Mica schist & Severe & Forest \\
\hline Pedon 6 & Side Slope & Moderately steep (10-15) & Quartzite & Severe & Pastures \\
\hline Pedon 7 & Side Slope & Moderate (5-10) & Mica schist & Moderate & Pastures \\
\hline Pedon 8 & Ridge top & Moderately steep (10-15) & Quartzite & Severe & Forest \\
\hline Pedon 9 & Ridge top & Steep (15-25) & Quartzite & Very severe & Shrubs and rocky land \\
\hline
\end{tabular}

Table.2 Morphological properties of the soils

\begin{tabular}{|c|c|c|c|c|c|c|c|c|c|c|c|}
\hline \multirow[t]{2}{*}{ Soils } & \multirow[t]{2}{*}{ Horizon } & \multirow{2}{*}{$\begin{array}{l}\text { Depth } \\
(\mathbf{c m})\end{array}$} & \multirow[t]{2}{*}{ Colour (moist) } & \multirow[t]{2}{*}{ Texture* } & \multirow[t]{2}{*}{ Structure*** } & \multicolumn{3}{|c|}{ Consistence $* * *$} & \multicolumn{2}{|c|}{ Boundary***** } & \multirow{2}{*}{$\begin{array}{c}\text { Coarse } \\
\text { fragments } \\
(\%)\end{array}$} \\
\hline & & & & & & D & $\mathbf{M}$ & $\mathbf{W}$ & D & $\mathbf{T}$ & \\
\hline \multirow[t]{7}{*}{ Pedon 1} & Ap & $0-13$ & $\begin{array}{c}\text { Brown } \\
\text { (10YR 4/3 M) }\end{array}$ & sl & $\mathrm{m}$ & sh & $\mathrm{fr}$ & ss,ps & $\mathrm{c}$ & $\mathrm{s}$ & 8 \\
\hline & A2 & $13-32$ & $\begin{array}{l}\text { Yellowish Brown } \\
\text { (10YR 5/4 M) }\end{array}$ & sl & f1sbk & - & fr & ss,ps & $\mathrm{g}$ & $\mathrm{s}$ & 8 \\
\hline & Bw1 & $32-53$ & $\begin{array}{c}\text { Brown } \\
(10 \text { YR 5/3 M) }\end{array}$ & sl & $\mathrm{m} 1 \mathrm{sbk}$ & - & $\mathrm{fr}$ & ss,ps & $\mathrm{g}$ & $\mathrm{s}$ & 9 \\
\hline & $\mathrm{Bw} 2$ & $53-75$ & $\begin{array}{c}\text { Brown } \\
(10 \text { YR 5/3 M) }\end{array}$ & sl & $\mathrm{m} 1 \mathrm{sbk}$ & - & fr & ss,ps & $\mathrm{g}$ & $\mathrm{s}$ & 10 \\
\hline & Bw3 & $75-101$ & $\begin{array}{c}\text { Brown } \\
(10 \text { YR 5/3 M) }\end{array}$ & sl & $\mathrm{m} 1 \mathrm{sbk}$ & - & $\mathrm{fr}$ & ss,ps & $\mathrm{g}$ & $\mathrm{s}$ & 9 \\
\hline & Bw4 & $101-125$ & $\begin{array}{c}\text { Brown } \\
(10 \text { YR 5/3 M) }\end{array}$ & sl & $\mathrm{m} 1 \mathrm{sbk}$ & - & fr & ss,ps & $\mathrm{c}$ & $\mathrm{s}$ & 11 \\
\hline & $\mathrm{C}$ & $125-157$ & $\begin{array}{c}\text { Brown } \\
(10 \text { YR 5/3 M) }\end{array}$ & sl & - & - & $\mathrm{fr}$ & ss,ps & - & - & 1 \\
\hline \multirow[t]{7}{*}{ Pedon 2} & Ap & $0-14$ & $\begin{array}{c}\text { Brown } \\
\text { (10YR 5/3 M) }\end{array}$ & gsl & $\mathrm{m}$ & sh & $\mathrm{fr}$ & ss,po & $\mathrm{c}$ & $\mathrm{s}$ & 30 \\
\hline & A2 & $14-37$ & $\begin{array}{c}\text { Brown } \\
(10 \text { YR 5/3 M) }\end{array}$ & gsl & $\mathrm{m}$ & - & $\mathrm{fr}$ & ss,po & $\mathrm{c}$ & $\mathrm{s}$ & 34 \\
\hline & A3 & $37-51$ & $\begin{array}{l}\text { Yellowish Brown } \\
\text { (10YR 5/4 M) }\end{array}$ & gsl & $\mathrm{m}$ & - & fr & ss,po & $\mathrm{g}$ & $\mathrm{s}$ & 37 \\
\hline & $\mathrm{AC}$ & $51-91$ & $\begin{array}{l}\text { Yellowish Brown } \\
\text { (10YR 5/4 M) }\end{array}$ & gsl & $\mathrm{m}$ & - & fr & ss,po & $\mathrm{c}$ & $\mathrm{s}$ & 41 \\
\hline & $\mathrm{C} 1$ & $91-117$ & $\begin{array}{c}\text { Brown } \\
\text { (10YR 5/3 M) }\end{array}$ & gsl & $\mathrm{m}$ & - & $\mathrm{fr}$ & ss,po & g & $\mathrm{s}$ & 44 \\
\hline & $\mathrm{C} 2$ & 117-139 & $\begin{array}{c}\text { Brown } \\
\text { (10YR 5/3 M) }\end{array}$ & gsl & $\mathrm{m}$ & - & fr & ss,po & g & $\mathrm{s}$ & 52 \\
\hline & $\mathrm{C} 3$ & $139-152$ & $\begin{array}{c}\text { Brown } \\
(10 \text { YR 5/3 M) }\end{array}$ & gsl & $\mathrm{m}$ & - & $\mathrm{fr}$ & ss,po & $\mathrm{a}$ & $\mathrm{s}$ & 54 \\
\hline
\end{tabular}




\begin{tabular}{|c|c|c|c|c|c|c|c|c|c|c|c|}
\hline \multirow[t]{5}{*}{ Pedon 3} & Ap & $0-11$ & $\begin{array}{c}\text { Brown } \\
(10 \text { YR 5/3 M) }\end{array}$ & ls & $\mathrm{sg}$ & 1 & vfr & so,po & $\mathrm{c}$ & $\mathrm{s}$ & 13 \\
\hline & A2 & $11-33$ & $\begin{array}{c}\text { Brown } \\
(10 \text { YR 5/3 M) }\end{array}$ & ls & $\mathrm{sg}$ & 1 & $\mathrm{vfr}$ & so,po & $\mathrm{c}$ & $\mathrm{s}$ & 15 \\
\hline & A3 & $33-61$ & $\begin{array}{l}\text { Yellowish Brown } \\
\text { (10YR 5/4 M) }\end{array}$ & $\mathrm{s}$ & $\mathrm{sg}$ & - & vfr & so,po & $\mathrm{g}$ & $\mathrm{s}$ & 18 \\
\hline & $\mathrm{C}$ & $61-85$ & $\begin{array}{l}\text { Yellowish Brown } \\
\text { (10YR 5/4 M) }\end{array}$ & $\mathrm{s}$ & $\mathrm{sg}$ & - & $\mathrm{vfr}$ & so,po & $\mathrm{a}$ & $\mathrm{s}$ & 19 \\
\hline & $\mathrm{Cr}$ & $85+$ & - & - & - & - & - & - & \multicolumn{2}{|c|}{$\begin{array}{l}\text { Unconsolidated } \\
\text { bedrock }\end{array}$} & - \\
\hline \multirow[t]{5}{*}{ Pedon 4} & Ap & $0-8$ & $\begin{array}{c}\text { Brown } \\
\text { (10YR 4/3 M) }\end{array}$ & $\mathrm{sl}$ & $\mathrm{m}$ & 1 & $\mathrm{fr}$ & ss,po & $\mathrm{c}$ & $\mathrm{s}$ & 17 \\
\hline & $\mathrm{A} 2$ & $8-24$ & $\begin{array}{c}\text { Brown } \\
\text { (10YR 5/3 M) }\end{array}$ & $\mathrm{sl}$ & $\mathrm{m}$ & - & $\mathrm{fr}$ & ss,po & $\mathrm{c}$ & $\mathrm{s}$ & 21 \\
\hline & A3 & $24-51$ & $\begin{array}{l}\text { Yellowish Brown } \\
\text { (10YR 5/4 M) }\end{array}$ & $\mathrm{sl}$ & $\mathrm{m}$ & - & $\mathrm{fr}$ & ss,po & $\mathrm{g}$ & $\mathrm{s}$ & 20 \\
\hline & $\mathrm{C}$ & $51-72$ & $\begin{array}{l}\text { Yellowish Brown } \\
\text { (10YR 5/4 M) }\end{array}$ & $\mathrm{sl}$ & $\mathrm{m}$ & - & $\mathrm{fr}$ & ss,po & $\mathrm{a}$ & $\mathrm{s}$ & 24 \\
\hline & $\mathrm{Cr}$ & $72+$ & - & - & - & - & - & - & \multicolumn{2}{|c|}{$\begin{array}{l}\text { Unconsolidated } \\
\text { bedrock }\end{array}$} & - \\
\hline \multirow[t]{5}{*}{ Pedon 5} & A1 & $0-13$ & $\begin{array}{c}\text { Brown } \\
\text { (10YR 5/3 M) }\end{array}$ & gls & $\mathrm{sg}$ & 1 & $\mathrm{vfr}$ & so,po & $\mathrm{c}$ & $\mathrm{s}$ & 29 \\
\hline & A2 & $13-32$ & $\begin{array}{c}\text { Brown } \\
\text { (10YR 5/3 M) }\end{array}$ & gls & $\mathrm{sg}$ & - & vfr & so,po & $\mathrm{c}$ & $\mathrm{s}$ & 37 \\
\hline & $\mathrm{C} 1$ & $32-52$ & $\begin{array}{l}\text { Yellowish Brown } \\
\text { (10YR 5/4 M) }\end{array}$ & gls & $\mathrm{sg}$ & - & vfr & so,po & g & $\mathrm{s}$ & 41 \\
\hline & $\mathrm{C} 2$ & $52-73$ & $\begin{array}{l}\text { Yellowish Brown } \\
\text { (10YR 5/4 M) }\end{array}$ & gls & $\mathrm{sg}$ & - & $\mathrm{vfr}$ & so,po & $\mathrm{a}$ & $\mathrm{s}$ & 47 \\
\hline & $\mathrm{Cr}$ & $73+$ & - & - & - & - & - & - & \multicolumn{2}{|c|}{$\begin{array}{l}\text { Unconsolidated } \\
\text { bedrock }\end{array}$} & - \\
\hline \multirow[t]{4}{*}{ Pedon 6} & A1 & $0-16$ & $\begin{array}{c}\text { Brown } \\
\text { (10YR 4/3 M) }\end{array}$ & sl & $\mathrm{m}$ & sh & $\mathrm{fr}$ & ss,po & $\mathrm{c}$ & $\mathrm{s}$ & 29 \\
\hline & A2 & $16-37$ & $\begin{array}{c}\text { Brown } \\
\text { (10YR 4/3 M) }\end{array}$ & gsl & $\mathrm{m}$ & - & $\mathrm{fr}$ & ss,po & $\mathrm{c}$ & $\mathrm{s}$ & 38 \\
\hline & $\mathrm{C}$ & $37-69$ & $\begin{array}{c}\text { Dark Yellowish } \\
\text { Brown } \\
\text { (10YR 4/4 M) }\end{array}$ & gsl & $\mathrm{m}$ & - & $\mathrm{fr}$ & ss,po & $\mathrm{a}$ & $\mathrm{s}$ & 44 \\
\hline & $\mathrm{R}$ & $69+$ & - & - & - & - & - & - & \multicolumn{2}{|c|}{$\begin{array}{c}\text { Indurated } \\
\text { bedrock }\end{array}$} & - \\
\hline \multirow[t]{4}{*}{ Pedon 7} & A1 & $0-11$ & $\begin{array}{c}\text { Brown } \\
(10 \mathrm{YR} 5 / 3 \mathrm{M})\end{array}$ & ls & $\mathrm{m}$ & 1 & vfr & so,po & $\mathrm{c}$ & $\mathrm{s}$ & 22 \\
\hline & A2 & $11-32$ & $\begin{array}{c}\text { Brown } \\
(10 \text { YR 5/3 M) }\end{array}$ & gls & $\mathrm{sg}$ & - & vfr & so,po & $\mathrm{c}$ & $\mathrm{s}$ & 38 \\
\hline & $\mathrm{C}$ & $32-48$ & $\begin{array}{l}\text { Yellowish Brown } \\
\text { (10YR 5/4 M) }\end{array}$ & gls & $\mathrm{sg}$ & - & vfr & so,po & $\mathrm{a}$ & $\mathrm{s}$ & 47 \\
\hline & $\mathrm{R}$ & $48+$ & - & - & - & - & - & - & \multicolumn{2}{|c|}{$\begin{array}{l}\text { Indurated } \\
\text { bedrock }\end{array}$} & - \\
\hline \multirow[t]{3}{*}{ Pedon 8} & A & $0-13$ & $\begin{array}{c}\text { Brown } \\
\text { (10YR 5/3 M) }\end{array}$ & gsl & $\mathrm{m}$ & sh & $\mathrm{fr}$ & ss,po & c & $\mathrm{s}$ & 38 \\
\hline & $\mathrm{C}$ & $13-32$ & $\begin{array}{c}\text { Yellowish } \\
\text { Brown } \\
\text { (10YR 5/4 M) }\end{array}$ & gsl & $\mathrm{m}$ & - & $\mathrm{fr}$ & ss,po & $\mathrm{a}$ & $\mathrm{s}$ & 52 \\
\hline & $\mathrm{R}$ & $32+$ & - & - & - & - & - & - & \multicolumn{2}{|c|}{$\begin{array}{c}\text { Indurated } \\
\text { bedrock }\end{array}$} & - \\
\hline
\end{tabular}




\begin{tabular}{|c|c|c|c|c|c|c|c|c|c|c|c|}
\hline \multirow{2}{*}{ Pedon 9} & A & $0-11$ & $\begin{array}{c}\text { Brown } \\
(10 \mathrm{YR} 4 / 3 \mathrm{M})\end{array}$ & gsl & $\mathrm{m}$ & 1 & $\mathrm{vfr}$ & ss,po & $\mathrm{a}$ & $\mathrm{s}$ & 49 \\
\hline & $\mathrm{R}$ & $11+$ & - & & - & - & - & - & \multicolumn{2}{|c|}{$\begin{array}{c}\text { Indurated } \\
\text { bedrock }\end{array}$} & - \\
\hline
\end{tabular}

*sl: sandy loam; gsl: gravelly sandy loam; ls: loamy sand; s: sand; gls: gravelly loamy sand

** m: massive; f 1 sbk: fine weak subangular blocky; $\mathrm{m} 1$ sbk: medium weak subangular blocky; sg: single grain;

***D:dry; M: moist; W:wet; sh:slightly hard; 1: loose; fr: friable; vfr: very friable; ss: slightly sticky; so: non-sticky; ps: slightly plastic: po: non-plastic

****D:distinctness; T:type; c: clear; g: gradual; a: abrupt; s: smooth

Table.3 Physico-chemical properties of the soils

\begin{tabular}{|c|c|c|c|c|c|c|c|c|c|c|c|c|c|c|}
\hline \multirow[t]{2}{*}{ Soils } & \multirow[t]{2}{*}{$\begin{array}{l}\text { Depth } \\
(\mathbf{c m})\end{array}$} & Sand & Silt & Clay & \multirow[t]{2}{*}{$\begin{array}{c}\text { pH } \\
(1: 2.5)\end{array}$} & \multirow{2}{*}{$\begin{array}{l}\text { EC } \\
(\mathrm{dS} \\
\left.\mathbf{m}^{-1}\right)\end{array}$} & \multirow[t]{2}{*}{$\begin{array}{l}\mathrm{OC} \\
(\%)\end{array}$} & \multicolumn{4}{|c|}{$\begin{array}{c}\text { Exchangeable cations } \\
{\left[\mathrm{cmol}(\mathrm{p}+) \mathrm{kg}^{-1}\right]}\end{array}$} & \multirow{2}{*}{$\begin{array}{c}\text { CEC } \\
{[\mathrm{cmol}(\mathrm{p}+} \\
\left.) \mathrm{kg}^{-1}\right]\end{array}$} & \multirow{2}{*}{$\begin{array}{l}\text { CEC/ } \\
\text { clay } \\
\text { ratio }\end{array}$} & \multirow{2}{*}{$\begin{array}{c}\text { Base } \\
\text { Saturation } \\
(\%)\end{array}$} \\
\hline & & & $\%$ & & & & & $\mathrm{Ca}$ & Mg & $\mathbf{N a}$ & $\mathbf{K}$ & & & \\
\hline \multirow{7}{*}{$\begin{array}{c}\text { Pedon } \\
1\end{array}$} & $0-13$ & 57.75 & 27.50 & 14.75 & 06.11 & 0.12 & 1.26 & 1.90 & 1.12 & 0.34 & 0.18 & 05.31 & 36.00 & 66.67 \\
\hline & $13-32$ & 56.75 & 30.50 & 12.75 & 06.35 & 0.13 & 0.49 & 1.78 & 0.92 & 0.21 & 0.11 & 04.46 & 34.98 & 67.71 \\
\hline & $32-53$ & 64.50 & 24.25 & 11.25 & 06.55 & 0.17 & 0.27 & 1.69 & 0.94 & 0.20 & 0.11 & 04.16 & 36.97 & 70.67 \\
\hline & 53-75 & 67.50 & 21.25 & 11.25 & 06.65 & 0.20 & 0.24 & 1.54 & 1.01 & 0.20 & 0.11 & 04.05 & 36.00 & 70.62 \\
\hline & 75-101 & 62.75 & 26.50 & 10.75 & 06.84 & 0.21 & 0.18 & 1.73 & 0.60 & 0.18 & 0.10 & 03.65 & 33.95 & 71.51 \\
\hline & $101-125$ & 58.50 & 27.00 & 14.50 & 06.89 & 0.26 & 0.10 & 2.61 & 0.69 & 0.28 & 0.15 & 05.07 & 34.96 & 73.57 \\
\hline & $125-157$ & 63.00 & 27.00 & 10.00 & 06.98 & 0.36 & 0.10 & 1.43 & 0.62 & 0.27 & 0.25 & 03.50 & 35.00 & 73.43 \\
\hline \multirow{7}{*}{$\begin{array}{l}\text { Pedon } \\
2\end{array}$} & $0-14$ & 64.75 & 20.75 & 14.50 & 06.14 & 0.13 & 1.25 & 1.97 & 0.63 & 0.15 & 0.09 & 04.35 & 30.00 & 65.29 \\
\hline & $14-37$ & 69.75 & 18.75 & 11.50 & 06.22 & 0.17 & 0.29 & 1.46 & 0.55 & 0.08 & 0.08 & 03.33 & 28.95 & 65.17 \\
\hline & $37-51$ & 60.25 & 27.25 & 12.50 & 06.32 & 0.19 & 0.29 & 1.53 & 0.69 & 0.11 & 0.05 & 03.50 & 28.00 & $68 . .00$ \\
\hline & $51-91$ & 58.25 & 27.75 & 14.00 & 06.39 & 0.33 & 0.29 & 1.49 & 0.78 & 0.24 & 0.10 & 03.78 & 27.00 & 69.05 \\
\hline & 91-117 & 71.00 & 16.75 & 12.25 & 06.71 & 0.37 & 0.18 & 1.54 & 0.67 & 0.15 & 0.05 & 03.43 & 28.00 & 70.26 \\
\hline & 117-139 & 70.25 & 14.25 & 15.50 & 06.77 & 0.49 & 0.14 & 1.57 & 1.05 & 0.28 & 0.09 & 04.18 & 26.96 & 71.53 \\
\hline & 139-152 & 68.75 & 16.25 & 15.00 & 06.81 & 0.51 & 0.12 & 1.60 & 1.07 & 0.28 & 0.09 & 04.20 & 28.00 & 72.38 \\
\hline \multirow{4}{*}{$\begin{array}{c}\text { Pedon } \\
3\end{array}$} & $0-11$ & 89.75 & 02.75 & 07.50 & 06.21 & 0.11 & 0.67 & 0.90 & 0.16 & 0.09 & 0.13 & 01.95 & 26.00 & 65.64 \\
\hline & $11-33$ & 83.00 & 09.90 & 07.10 & 06.38 & 0.20 & 0.19 & 0.48 & 0.42 & 0.20 & 0.11 & 01.78 & 25.07 & 67.98 \\
\hline & $33-61$ & 92.20 & 04.80 & 03.00 & 06.43 & 0.29 & 0.15 & 0.25 & 0.12 & 0.10 & 0.07 & 00.78 & 26.00 & 69.23 \\
\hline & $61-85$ & 93.15 & 04.10 & 02.75 & 06.48 & 0.35 & 0.14 & 0.23 & 0.09 & 0.09 & 0.07 & 00.68 & 24.72 & 70.59 \\
\hline \multirow{4}{*}{$\begin{array}{c}\text { Pedon } \\
4\end{array}$} & $0-8$ & 58.10 & 27.40 & 14.50 & 05.66 & 0.10 & 2.07 & 1.83 & 0.58 & 0.16 & 0.19 & 04.64 & 32.07 & 59.48 \\
\hline & $8-24$ & 53.58 & 31.42 & 15.00 & 05.79 & 0.11 & 0.82 & 2.15 & 0.47 & 0.16 & 0.08 & 04.66 & 31.06 & 61.37 \\
\hline & $24-51$ & 54.25 & 30.25 & 15.50 & 06.15 & 0.13 & 0.61 & 1.78 & 0.44 & 0.19 & 0.10 & 04.03 & 26.00 & 62.28 \\
\hline & $51-72$ & 53.95 & 31.05 & 15.00 & 06.34 & 0.28 & 0.52 & 1.67 & 0.36 & 0.15 & 0.16 & 03.75 & 25.00 & 62.40 \\
\hline \multirow{4}{*}{$\begin{array}{c}\text { Pedon } \\
5\end{array}$} & $0-13$ & 84.75 & 07.50 & 07.75 & 05.61 & 0.12 & 1.21 & 0.58 & 0.32 & 0.11 & 0.09 & 02.17 & 28.00 & 50.69 \\
\hline & $13-32$ & 84.00 & 07.50 & 08.50 & 05.74 & 0.14 & 0.69 & 0.67 & 0.40 & 0.12 & 0.11 & 02.46 & 28.94 & 52.84 \\
\hline & $32-52$ & 83.75 & 08.50 & 07.75 & 05.82 & 0.19 & 0.15 & 0.59 & 0.34 & 0.11 & 0.11 & 02.17 & 28.00 & 52.99 \\
\hline & $52-73$ & 81.50 & 10.50 & 08.00 & 05.92 & 0.41 & 0.15 & 0.58 & 0.40 & 0.10 & 0.11 & 02.16 & 27.00 & 55.09 \\
\hline \multirow{3}{*}{$\begin{array}{l}\text { Pedon } \\
6\end{array}$} & $0-16$ & 54.75 & 35.50 & 09.75 & 05.52 & 0.16 & 1.86 & 0.82 & 0.48 & 0.16 & 0.15 & 03.02 & 30.97 & 53.31 \\
\hline & $16-37$ & 53.00 & 37.50 & 09.50 & 06.21 & 0.30 & 1.02 & 0.87 & 0.52 & 0.15 & 0.14 & 03.04 & 32.00 & 55.26 \\
\hline & $37-69$ & 52.50 & 36.25 & 11.25 & 06.34 & 0.36 & 0.79 & 1.21 & 0.52 & 0.14 & 0.05 & 03.37 & 29.95 & 56.97 \\
\hline \multirow{3}{*}{$\begin{array}{l}\text { Pedon } \\
7\end{array}$} & $0-11$ & 75.25 & 16.25 & 08.50 & 06.34 & 0.12 & 0.77 & 1.01 & 0.35 & 0.10 & 0.07 & 02.55 & 30.00 & 60.00 \\
\hline & $11-32$ & 83.50 & 08.50 & 08.00 & 06.43 & 0.14 & 0.38 & 0.86 & 0.40 & 0.16 & 0.01 & 02.32 & 29.00 & 61.64 \\
\hline & $32-48$ & 83.50 & 08.25 & 07.25 & 06.49 & 0.14 & 0.23 & 0.71 & 0.35 & 0.18 & 0.04 & 02.03 & 28.00 & 63.05 \\
\hline \multirow{2}{*}{$\begin{array}{l}\text { Pedon } \\
8\end{array}$} & $0-13$ & 53.15 & 31.85 & 15.00 & 05.64 & 0.02 & 1.48 & 2.22 & 0.29 & 0.09 & 0.13 & 05.10 & 34.00 & 53.53 \\
\hline & $13-32$ & 56.45 & 31.05 & 12.50 & 05.95 & 0.03 & 0.66 & 1.95 & 0.15 & 0.06 & 0.13 & 04.12 & 32.96 & 55.58 \\
\hline $\begin{array}{c}\text { Pedon } \\
9\end{array}$ & $0-11$ & 65.35 & 22.90 & 11.75 & 05.86 & 0.02 & 1.23 & 1.57 & 0.09 & 0.07 & 0.08 & 03.52 & 29.96 & 51.42 \\
\hline
\end{tabular}


Table.4 Soil classification

\begin{tabular}{|c|c|c|}
\hline Soils & Description & Taxonomy \\
\hline Pedon 1 & $\begin{array}{l}\text { Very deep with A, B and C horizons, well drained, sandy loam } \\
\text { soils of brown colour developed on Alluvium. }\end{array}$ & $\begin{array}{l}\text { Very deep, mixed, thermic, coarse } \\
\text { loamy, DystricEutrudepts. }\end{array}$ \\
\hline Pedon 2 & $\begin{array}{l}\text { Very deep with } \mathrm{A} \text { and } \mathrm{C} \text { horizons, well drained, sandy loam } \\
\text { soils of brown to yellowish brown colour developed on } \\
\text { Alluvium. }\end{array}$ & $\begin{array}{l}\text { Very deep, mixed, thermic, loamy, } \\
\text { skeletal, TypicUdorthents. }\end{array}$ \\
\hline Pedon 3 & $\begin{array}{l}\text { Moderately shallow with A-C horizons, somewhat excessively } \\
\text { drained, sandy soils of brown to yellowish brown in colour } \\
\text { developed on Alluvium/Colluvium. }\end{array}$ & $\begin{array}{l}\text { Moderately shallow, mixed, } \\
\text { thermic, TypicUdipsamments. }\end{array}$ \\
\hline Pedon 4 & $\begin{array}{l}\text { Moderately deep with } \mathrm{A} \text { and } \mathrm{C} \text { horizons, well drained, sandy } \\
\text { loam soils of brown to yellowish brown in colour developed on } \\
\text { Mica schist. }\end{array}$ & $\begin{array}{l}\text { Moderately deep, mixed, thermic, } \\
\text { coarse loamy, TypicUdorthents. }\end{array}$ \\
\hline Pedon 5 & $\begin{array}{l}\text { Moderately shallow with A-C horizons, excessively drained, } \\
\text { loamy sand soils of brown to yellowish brown in colour } \\
\text { developed on Mica schist. }\end{array}$ & $\begin{array}{l}\text { Moderately shallow, mixed, } \\
\text { thermic, sandy skeletal, } \\
\text { TypicUdorthents. }\end{array}$ \\
\hline Pedon 6 & $\begin{array}{l}\text { Moderately shallow with A-C horizons, somewhat excessively } \\
\text { drained, sandy loam soils of brown to dark yellowish brown in } \\
\text { colour developed on Quartzite. }\end{array}$ & $\begin{array}{l}\text { Moderately shallow, mixed, } \\
\text { thermic, loamy skeletal, } \\
\text { TypicUdorthents. }\end{array}$ \\
\hline Pedon 7 & $\begin{array}{l}\text { Shallow with A-C horizons, somewhat excessively drained, } \\
\text { loamy sand soils of brown to yellowish brown colour developed } \\
\text { on Alluvium. }\end{array}$ & $\begin{array}{l}\text { Shallow, mixed, thermic, sandy } \\
\text { skeletal, Lithic Udorthents. }\end{array}$ \\
\hline Pedon 8 & $\begin{array}{l}\text { Shallow with A-C horizons, excessively drained, sandy loam } \\
\text { soils of brown to yellowish brown in colour developed on } \\
\text { Alluvium. }\end{array}$ & $\begin{array}{l}\text { Shallow, mixed, thermic, loamy } \\
\text { skeletal, Lithic Udorthents. }\end{array}$ \\
\hline Pedon 9 & $\begin{array}{l}\text { Very shallow with A-C horizons, excessively drained, sandy } \\
\text { loam soils of brown colour developed on Quartzite. }\end{array}$ & $\begin{array}{l}\text { Very shallow, mixed, thermic, } \\
\text { loamy skeletal, Lithic Udorthents. }\end{array}$ \\
\hline
\end{tabular}


Table.5 Land categorisation and suggested measures

\begin{tabular}{|c|c|c|c|}
\hline Soils & Limitations & $\begin{array}{c}\text { Land } \\
\text { Categories }\end{array}$ & Suggested measures \\
\hline Pedon 1 & $\begin{array}{l}\text { Undulating land, coarser texture, } \\
\text { slight erosion and low nutrient } \\
\text { holding capacity }\end{array}$ & Class III & $\begin{array}{l}\text { Land leveling, adoption of integrated nutrient } \\
\text { management (INM) practices including required } \\
\text { doses of organic and inorganic manures and } \\
\text { fertilisers. }\end{array}$ \\
\hline Pedon 2 & $\begin{array}{l}\text { Undulating land, coarser texture } \\
\text { with strong gravels, slight } \\
\text { erosion and low nutrient holding } \\
\text { capacity }\end{array}$ & Class III & $\begin{array}{l}\text { Land leveling, adoption of INM practices including } \\
\text { recommended doses of organic and inorganic } \\
\text { manures and fertilisers, selection of crops adapted to } \\
\text { limitations of soils. }\end{array}$ \\
\hline Pedon 3 & $\begin{array}{l}\text { Limited soil depth, sandy texture } \\
\text { moderate slope with moderate } \\
\text { erosion and very low nutrient } \\
\text { holding capacity }\end{array}$ & Class V & $\begin{array}{l}\text { Not suitable for cultivation but suitable for pastures, } \\
\text { can be utilised for cultivation with proper soil and } \\
\text { water conservation measures including high doses of } \\
\text { organic and inorganic fertilizers, timely and sufficient } \\
\text { irrigations and selection of crops adapted to limitation } \\
\text { of soils. }\end{array}$ \\
\hline Pedon 4 & $\begin{array}{l}\text { Limited soil depth, coarser } \\
\text { texture, moderate slope with } \\
\text { moderate erosion, moderate } \\
\text { stoniness and low nutrient } \\
\text { holding capacity }\end{array}$ & Class IV & $\begin{array}{l}\text { Adoption of proper soil and water conservation } \\
\text { practices to prevent erosion and selection of plants } \\
\text { adopted to limitation of soils. }\end{array}$ \\
\hline Pedon 5 & $\begin{array}{l}\text { Limited soil depth, very coarser } \\
\text { texture with strong gravels, steep } \\
\text { slopes and severe erosion and } \\
\text { very low nutrient holding } \\
\text { capacity }\end{array}$ & Class VI & $\begin{array}{l}\text { Not suitable for cultivation, but can be utilised for } \\
\text { grazing/pastures/forestry with proper engineering } \\
\text { structures to prevent erosion. }\end{array}$ \\
\hline Pedon 6 & $\begin{array}{l}\text { Limited soil depth, coarser } \\
\text { texture with strong gravels, } \\
\text { moderate steep slopes and } \\
\text { severe erosion and low nutrient } \\
\text { holding capacity }\end{array}$ & Class V & $\begin{array}{l}\text { Not suitable for cultivation but suitable for pastures, } \\
\text { can be brought under cultivation, adopting } \\
\text { conservation measures like construction of } \\
\text { engineering structures to prevent erosion, good } \\
\text { agronomic practices and selection of plants adapted to } \\
\text { limitation of soils. }\end{array}$ \\
\hline Pedon 7 & $\begin{array}{l}\text { Sloppy landscape, shallow soil } \\
\text { depth, very coarser soil texture } \\
\text { with strong gravels and very low } \\
\text { nutrient holding capacity }\end{array}$ & Class VI & $\begin{array}{l}\text { Not suitable for cultivation, but can be utilised for } \\
\text { pastures, adoption of proper soil and water } \\
\text { conservation measures to prevent erosion. }\end{array}$ \\
\hline Pedon 8 & $\begin{array}{l}\text { Shallow soil depth, coarser } \\
\text { texture with strong gravels, } \\
\text { moderately steep slopes with } \\
\text { severe erosion and low nutrient } \\
\text { holding capacity }\end{array}$ & Class VI & $\begin{array}{l}\text { Not suitable for cultivation, but can be utilised for } \\
\text { grazing/plantations after construction of proper } \\
\text { engineering structures to prevent erosion. }\end{array}$ \\
\hline Pedon 9 & $\begin{array}{l}\text { Very shallow soil depth, coarser } \\
\text { texture with strong gravels, steep } \\
\text { slopes with very severe erosion } \\
\text { and low nutrient holding } \\
\text { capacity }\end{array}$ & Class VII & $\begin{array}{l}\text { Not suitable for cultivation and plantations, can be } \\
\text { utilised for grazing/pastures after construction of } \\
\text { proper engineering structures to prevent erosion. }\end{array}$ \\
\hline
\end{tabular}


Fig.1 Study Area: Bino-river watershed, Almora District, Uttarakhand, India

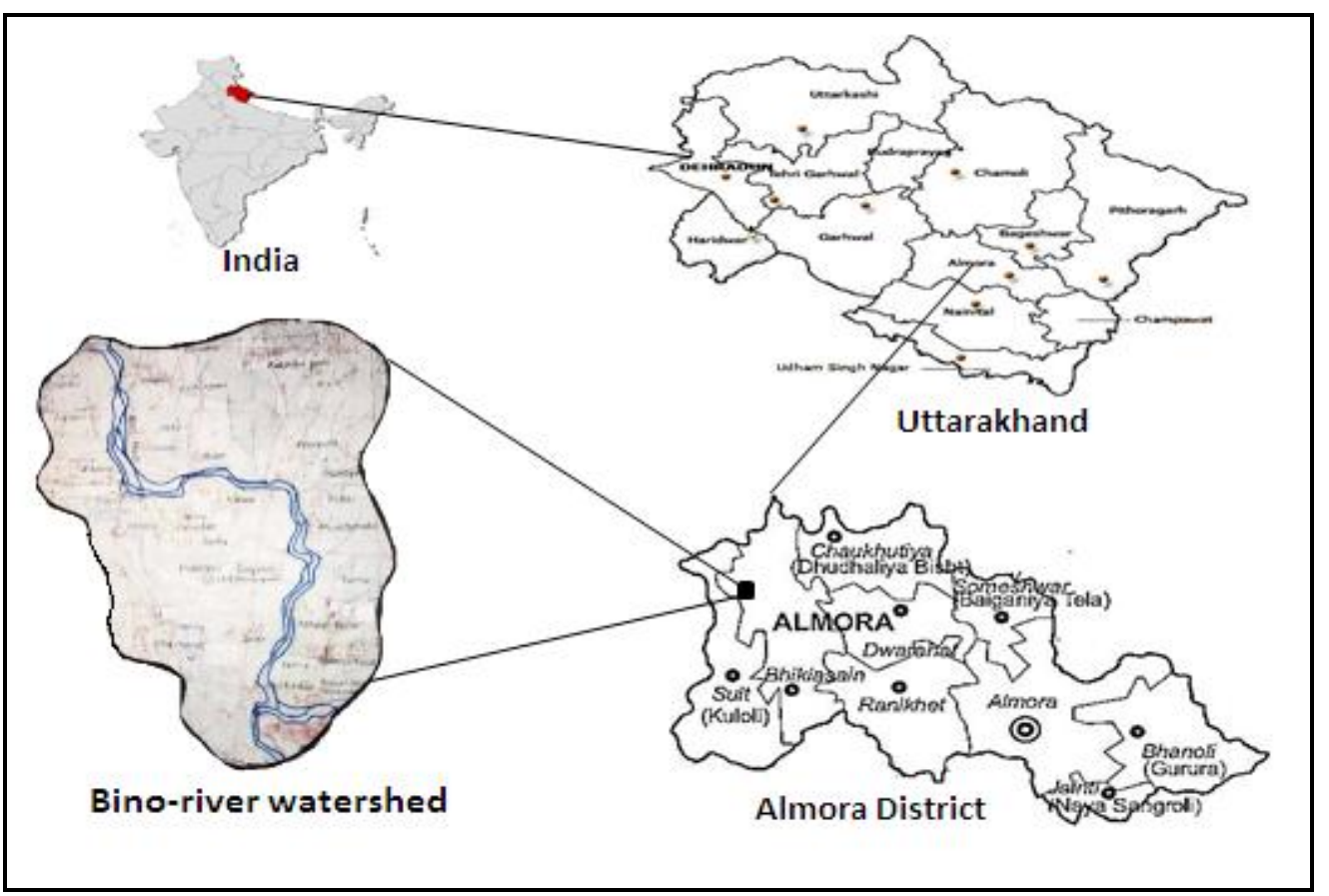

Fig.2 Soil Landscape Relationship of Bino-River Watershed

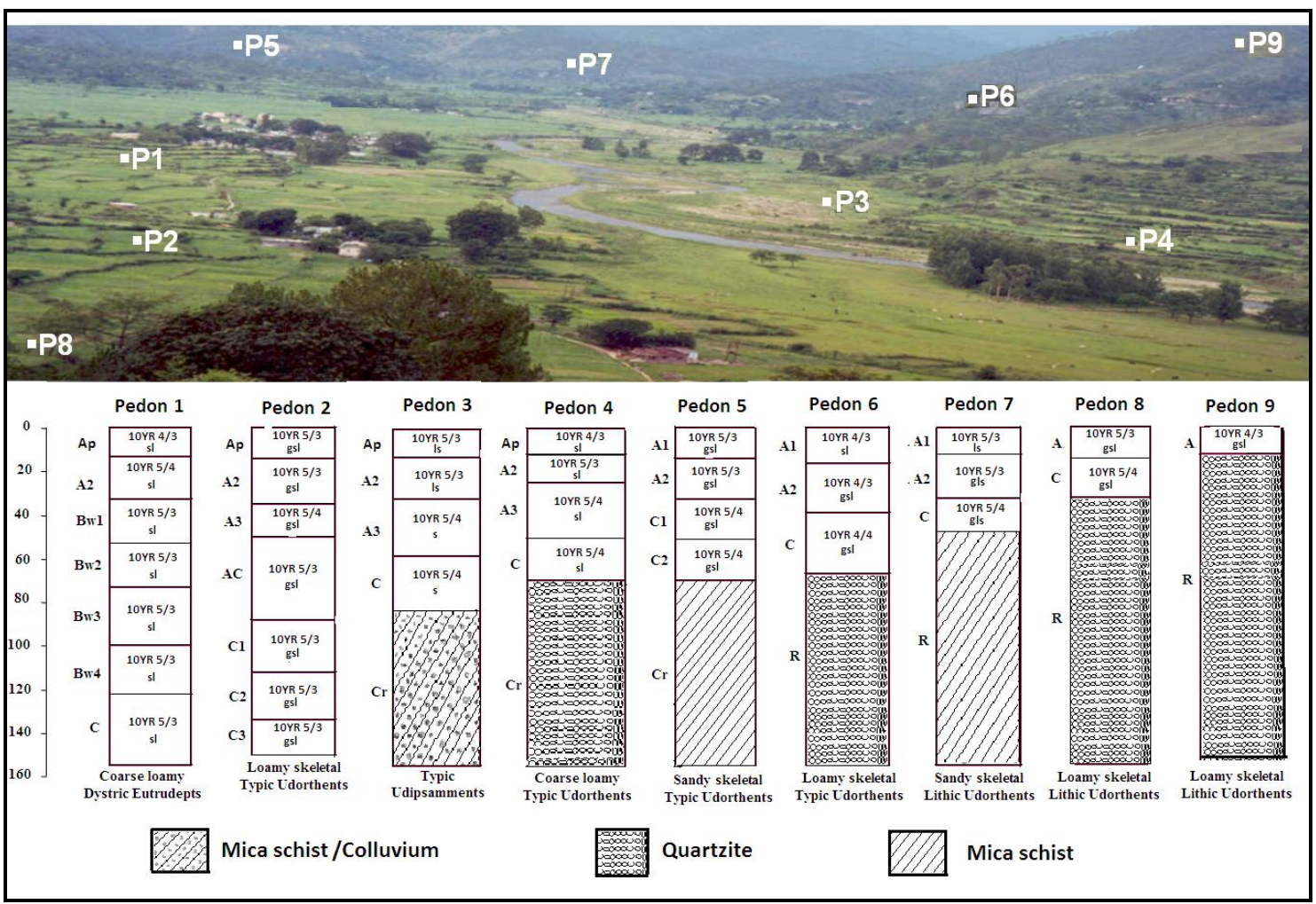


Soils of the Bino-river watershed in Almora district of Uttarakhand in India have been characterised and classified for land evaluation and conservation of natural resources. Nine types of soils have been found occurring on three major landforms viz., moderately steep to steeply sloping ridge tops, moderate to steep side slopes and gentle to moderately sloping valleys. Eight soils belong to Entisols having only $\mathrm{A}$ and $\mathrm{C}$ horizons whereas only one soil occurring on fluvial valleys belongs to Inceptisols having A-B-C horizons. The major limitations of the watershed are sloppy landscape, limited soil depth, moderate to severe erosion, strong gravelliness and low to very low nutrient holding capacity. Soils are evaluated as class III land on fluvial valleys, class IV and VI lands on side slopes and class VI and VII lands on ridge tops, respectively. Proper soil and water conservation measures as well as good agronomic practices may be adopted for enhancing productivity and overall development of this hilly area.

\section{Acknowledgement}

Authors express their sincere thanks and gratitude to the Director, ICAR-NBSS\&LUP, Nagpur, Maharashtra, India for providing required facilities and kind support to carry out the present research work.

\section{References}

Bhattacharya, T., Sarkar, Dipak and Pal, D.K. (Eds.) 2009. Soil Survey Manual. NBSS\&LUP, Publ. No.146, pp. 400.

Biswas, R.R. 1987. A soil map through landsat satellite imagery in part of the Auranga catchment in the Ranchi and Palamou districts of Bihar, India. International Journal of Remote Sensing4: 541-543.

Black, C.A. (Ed.) 1965. Methods of Soil Analysis. Part I. American Society
Madison, Wisconsis, USA.

Blum W.E.H.1997. Basic concepts: degradation, resilience, and rehabilitation. In Methods for Assessment of Soil Degradation. (R. Lal, W.R.H. Blum, C. Valentine and B.A. Stewart, Eds.), CRC Press, New York. pp. 16.

Dhyani, S.K., Sharda, V.N. and Samra, J.S. 2005. Agroforestry for sustainable management for soil, water and environment quality: looking back to think ahead. Range Mgmt. and Agroforestry, 26 (1): 71-83.

Divakar, B.L., Bhagat, K.N., Tewari, J.C. and Mehta, N.S. 1989. Soil fertility status of horticultural areas in Nainital district of U.P. hills (hilly region). Progressive Horticulture 21, 95-99.

FAO, 2015.Understanding Mountain Soils: A contribution from mountain areas to the International Year of Soils 2015, by Romeo, R., Vita, A., Manuelli, S., Zanini, E., Freppaz, M. and Stanchi, S. Rome, Italy. (www.fao.org/ publications). Ghosh, B.N. and Singh, R.D. 2002. Suitability of soil test methods for available phosphorus and its critical levels for maize in acid soils of Uttaranchal hills. Journal of the Indian Society of Soil Science 50,132-134.

Gorai, T., Ahmed, N., Mahapatra, S.K.,Datta S.C., Singh, R.D., and Sharma, R.K. 2013.Effect of topography and vegetation on soil development in Kumaon hills of North Western Himalayas. Journal of Soil and water Conservation 12: 269-276.

Jackson, M.L. 1966. Soil Chemicals Analysis. Prentice Hall of India (Pvt.) Ltd., New Delhi. Kumar, S. and Sharma, A.K. 1987. Numerical classification of some hill soils of Uttar Pradesh. Journal of the Indian Society of Soil Science 35, 465-473. 
Mahapatra, S.K., Jagat Ram, Singh, S.P. and Dhankar, R.P. 2005. Soil Resource Inventory of Warm Humid Kumaon Himalayas for Sustainable Land Use. Journal of the Indian Society of Soil Science 53: 390-393.

Mahapatra, S.K., Reddy, G.P. Obi, Nagdev, Ritu, Yadav, R.P., Singh, S.K. and Sharda. V.N. 2018. Assessment of soil erosion in fragile Himalayan ecosystem of Uttarakhand using USLE and GIS for sustainable productivity. Current Science.115 (1) 108-121.

Mahapatra, S.K., Walia, C.S., Sidhu, G.S., Rana, K.P.C. and TarsemLal.2000. Characterization and classification of the soils of different physiographic units in the sub humid eco-system of Kashmir region. Journal of the Indian Society of Soil Science 48, 572-577.

Mishra, B.B. and Ghosh, S.K. 1995. Characteriztion of soils derived from mica rich parent materials in two toposequences. Journal of the Indian Society of Soil Science43: 92-98.

Nagdev, Ritu, Mahapatra, S.K., Yadav, R.P. and Singh, S.K. 2017a. Delineation and Characterization of PurviNayyar River Watershed in Mid- Himalayan Region of India Using Remote Sensing and GIS Techniques. International Journal of Current Microbiology and Applied Sciences.6 (9): 2047-2062.

Nagdev, Ritu, Mahapatra, S.K. and Yadav, R.P. 2017b. Assessment of AgriEnvironment in Garhwal Himalayas of India for Sustainable Productivity. International Journal of Ecology and Environmental Sciences, 43(4): 295307.

Nagdev, Ritu, Mahapatra, S.K., Yadav, R.P. and Singh, S.K. 2017c. Assessment of Soil Resource Potential of Warm Humid Kumaon Himalayas for
Sustainable Productivity. Journal of the Indian Society of Soil Science65 (2): 138-147.

Nagdev, Ritu, Mahapatra, S.K., Yadav, R.P. and Singh, S.K. 2017d. Land Capability Classification and Management needs in Aravalli fringes in Southern Haryana for Sustainable Land Use Planning. Journal of Soil and Water Conservation, 16(2): 117125.

Nagdev, Ritu, Mahapatra, S.K., Yadav, R.P., Singh, S.K. and Surya Jaya N., 2018.Role of soil clays for watershed management in Mewat region of Haryana. Clay Research37 (1): 23-31.

Pai C.W., Wang M.K. and Chiu, C.Y. 2007. Clay mineralogical characterization of a toposequence of perhumid subalpine forest soils in north eastern Taiwan. Geoderma138: 177-184.

Prasad, R. and Dhyani, S.K. 2010. Review of agroforestry contributions and problems in arid ecosystem for livelihood support in India. Journal of Soil and Water Conservation, 9(4): 277-287.

Rawat, G.S., Ramana Murthy, J., Suman Kumar, Murthy, R.J. and Kumar, S. 1994. Characteristics and classification of soils of Shivaliks in relation to land use. Advances in Forestry Research in India 10: 45-53.

Sahu, Nisha, Singh, S.K., Obi Reddy, G.P., Nirmal Kumar, Nagaraju, M.S.S. and Srivastava, Rajeev.2016. Large scale soil resource mapping using IRS P6 LISS IV and Cartosat-1 DEM in basaltic terrain of Central India. Journal of Indian Society of Remote Sensing, 44, 811-819.

Sehgal, J.L., Saxena, R.K. and Vadivelu, S. 1987. Field Manual: Soil Resource Mapping of Different States. Bulletin 13, NBSS\&LUP, Nagpur.

Sehgal, J. 1996. Pedology-concepts and 
applications. First Edition, Kalyani publishers, New Delhi. Sharma, V.A.K., Krishnan, P. and Budhial, S.L. 1987. Laboratory Methods: Soil Resource, Mapping of Different States in India. Bulletin14, NBSS\&LUP, Nagpur. Singh, R.D. and Bhatnagar, V.K. 1997. Differences in soil and leaf litter nutrient status under Pinus, Cedrus and Quercus. Indian Journal of Forestry20, 147-149.

Smith, G.D. 1986. The Guy D Smith Interviews: Rationales for concept in Soil Taxonomy. (SMSS Technical Monograph 11, SMSS, SCS, USDA.

Soil Survey Staff. 2014. Keys to Soil Taxonomy. Natural Resources Conservation Service, Washington,
D.C., USA.pp 360.

Sys, C. 1985.Land Evaluation. Part II. Agriclas, Publication 7, Ghent, Belgium pp. 143-157.

Velayutham, M., Mandal, D.K.,Mandal, Champa and Sehgal, J. 1999.Agroecological sub-regions of India for planning and development. NBSS Publ. 35, NBSS\&LUP, Nagpur, India, 1-372.

Walia, C.S., Surya, Jaya, N., Dhankar, R.P., Sharma, J.P. and Sarkar, Dipak. 2013. Generation of soil database for Khulgad watershed development in Almora district of Uttarakhand. NBSS Publication 1043, NBSS\&LUP, Nagpur, India, Pp. 1-130.

\section{How to cite this article:}

Mahapatra, S.K., Ritu Nagdev, R.P. Yadav and Singh, S.K. 2019. Characterization and Classification of the Soils of Bino-River Watershed in Almora District of Uttarakhand, India for Perspective Land Use Planning. Int.J.Curr.Microbiol.App.Sci. 8(03): 207-222. doi: https://doi.org/10.20546/ijcmas.2019.803.028 